\title{
ARTICLE
}

\section{Handling COVID-19 from a Collaborative Governance Perspective in Pekanbaru City}

\author{
Raja Muhammad Amin ${ }^{1}$, Rury Febrina (iD ${ }^{2}$, Baskoro Wicaksono (iD ${ }^{3}$ \\ 1,2,3 Department of Governmental Science, Faculty of Social and Political Sciences, University of Riau, \\ Indonesia \\ $\square$ rury.febrina@lecturer.unri.ac.id
}

\section{OPEN ACCESS}

Citation: Amin, R. M., Febrina, R., \& Wicaksono, B. (2021). Handling COVID-19 from a Collaborative Governance Perspective in Pekanbaru City. Jurnal Bina Praja, 13(1), 1-13. https://doi.org/10.21787 jbp.13.2021.1-13

Received: January 04, 2021 Accepted: March 23, 2021 Published: April 30, 2021

(c) The Author(s)

\section{c) 0 (9)}

This work is licensed under a Creative

Commons Attribution-NonCommercial-

ShareAlike 4.0 International License.
Abstract: Identical collaborative governance is used in government and must handle COVID-19 to create fast, precise, focused, integrated and synergistic steps between ministries/agencies, local governments, and other stakeholders. This research describes collaborative governance in efforts to deal with COVID-19 in Riau Province, especially Pekanbaru City, considering that the city recorded a relatively high initial increase in cases compared to other areas in Riau Province as well as the implementation of collaborative management. The research method is qualitative, with the type of research used is the exploratory type and literature study. This article analyses several aspects of collaborative governance, namely the initial role of the government, non-state actors, joint decision making, formal organizing, gaining consensus, and the existence of problems to collaborate both on public policies and services.

Keywords: Collaborative Governance, Non-State Actors, COVID-19 


\section{Introduction}

Corona Virus Disease 2019 (COVID-19) is a new phenomenon that occurred in December in Wuhan, China. The spread of COVID-19 in the world continues to increase and has implications for all aspects of people's lives. The most significant impact is on the poor and vulnerable, the direct effects of the public health crisis on health and death, and the indirect effects on the social, economic, and political system. (Económico, 2020). The presence of COVID-19 challenges national preparedness and response capabilities to the pandemic (Shaw et al., 2020). At the beginning of the emergence of COVID-19, Governments in various parts of the world were not ready to face and handle it. However, with a broad impact on all aspects, it became imperative to respond to the pandemic as effectively and efficiently as possible and a lesson for future preparedness. The role of international cooperation and the multilateral system is critical in handling COVID-19 and the need for efficient cooperation mechanisms between the government, the private sector, and civil society (OECD, 2020b); (Kisielewska \& Richter, 2020). In addition, it is necessary to integrate the territorial dimension in the national investment recovery strategy and involve local governments in its implementation from an early age, and not only in cities but also in other regions. (Allain-Dupré et al., 2020).

COVID-19 has been declared a non-natural disaster in Indonesia, and the public health emergency due to COVID-19 was declared on April 13, 2020, through Presidential Decree No. 12 of 2020. Policy responses to COVID-19 differ across regions and largely reflect i) the government's assessment of the health situation and ii) fiscal capacity (Balakrishnan, 2020). Public health policies issued require an emphasis on comprehensive testing that needs to be complemented by selective quarantine measures (Égert et al., 2020). One of the policies related to the determination of health emergencies is health quarantine in large-scale social restrictions. The response of the Indonesian government regarding the prevention of COVID-19 is through early detection, human surveillance, environmental monitoring, an inspection of transportation means, and inspection of goods (Sukmana et al., 2020). The need for a risk assessment of a pandemic, understanding the main intervention areas for COVID-19 response and management as a database, apart from being an early detection mechanism it is also able to influence public awareness-raising and input for decision making (Chatterjee et al., 2020). Looking to the long term, to pave the way for greater resilience from COVID-19, the government must prioritize strengthening dialogue mechanisms and adopting cross-government strategies. (OECD, 2020a).

This pandemic is a difficult time in making decisions that are very impactful and must be carried out quickly. There is no further provision from Law no. 6 of 2018 concerning Health Quarantine is the main obstacle in standardizing the implementation of LargeScale Social Restrictions. In the context of integrated efforts to anticipate the wider impact of the spread of COVID-19, both between ministries/agencies and the local government to form a Task Force for the Acceleration of Handling COVID-19.

The complexity of the problems related to the impact of COVID-19 requires governance that is responsive and adaptive to conditions so that it affects the government of the crisis/risk faced due to the spread of COVID-19 by emphasizing collaborative action (Djalante et al., 2020). The Provincial Government has followed up on handling COVID 19 in Riau Province by establishing a Non-Natural Disaster Emergency Alert Status due to Corona Virus in Riau Province through the Decree of the Governor of Riau Number: Kpts.596 / III / 2020. This policy considers the President's direction on March 15, 2020, which emphasizes the existence of efforts to monitor regional conditions and patterns of coordination and consultation in assessing the situation in the regions. The region with the highest spread rate and positive cases of COVID-19 is Pekanbaru City compared to other districts/cities. The characteristics of urban areas with a dense population, high mobility of the people, and directly adjacent to several other provinces are challenging in dealing with COVID-19. The Pekanbaru City Government issued several strategic policies as a solution in preventing COVID-19, 
such as establishing an emergency response status due to COVID-19, giving guidelines for implementing Large-Scale Social Restrictions, forming a task force, and imposing Large-Scale Social Restrictions in Handling COVID-19 in Pekanbaru City.

Handling COVID-19 emphasizes the importance of coordination, cooperation, and synergy and the formation of a task force team that focuses on accelerating the handling of COVID-19. This collaboration is important to elaborate on which governance processes are identical to using collaborative governance. This article is focused on handling COVID-19, especially on the implementation of Large-Scale Social Restrictions in Pekanbaru City, which is carried out in three stages. This underlies this article which aims to explore the handling of COVID-19 from the perspective of collaborative governance in Pekanbaru City.

Handling COVID-19 emphasizes the importance of coordination, cooperation, and synergy and the formation of a task force team that focuses on accelerating the handling of COVID-19. This collaboration is important to elaborate on which governance processes are identical to using collaborative governance. This article is focused on handling COVID-19, especially on the implementation of Large-Scale Social Restrictions in Pekanbaru City, which is carried out in three stages. This is what underlies this article which aims to explore the handling of COVID-19 from the perspective of collaborative governance in Pekanbaru City.

Collaborative governance in the last two decades has emerged as an important and ideal approach in the governance process and public policy. Collaborative governance is adaptive management to ensure implementation and sustainability (Mukhlis et al., 2018). The paradigm of governance or governance in a government perspective is not only monopolized by the government (Arrozaaq, 2016). In the governance process, identical governance uses collaborative government governance, which includes non-state actors in decision-making. In addition, according to Ansell and Gash, collaborative governance in government (Mukhlis et al., 2018) states that in government governance and public policy, it is said to use collaborative governance when six elements characterize it;

1. The initial role of government

2. The inclusion of non-state actors

3. Joint decision making

4. Formal organizing

5. Getting consensus

6. There are problems with collaborating on both public policies and services.

The six elements in collaborative governance are also part of good governance principles, so that collaborative governance is an empirical practice of the concept of good governance. According to Davis and Keating, as cited in (Mukhlis et al., 2018), the concept of good governance explains how the government system operates with a wider scope of roles, covering the government and covering the government, including non-governmental organizations. and civilians. This means that the interaction between actors (government and non-governmental organizations) in collaboration will contribute to the realization of good governance.

An important note for the challenges that arise in collaborative governance; it takes a long time, issues of equality and trust, and interdependence between actors. Meanwhile, the perspective of the role of public managers emphasizes the challenges implicit in collaborative governance, social dynamics about the ambiguity and complexity of membership, tensions between stakeholders, and the dominance of formal power structures (P.P. et al., 2018). Collaborative governance is a complex structure in which there are possible imbalances between stakeholders. Collaboration forums are a place to bring together various interests of various stakeholders to achieve a win-win solution due to interdependence (Furqoni \& Rosyadi, 2019). The collaboration perspective also defines government as managing networks, especially with non-state actors (Subhan, 2016). "Multipartner Governance" is considered capable of describing this collaboration, starting from the formulation of plans that emphasize cooperation between the government and the private sector and the 
government and the community (Astari, M. M., Mahsyar, A., \& Parawangi, 2019). Within the framework of collaborative cooperation, each actor still has the authority to make decisions independently. The collaboration stage emphasizes the existence of a common vision and common goals, strategies and activities carried out. (Sepriandi \& Hussein, 2019).

\section{Methods}

The method used in this research is the qualitative method. According to Bogdan and Taylor in Moleong, qualitative methods are research procedures that produce descriptive data in the form of written or spoken words from people and observable behavior (Moleong, 2007). The type of research used is the exploratory type and literature study, which is a research model that seeks to create a description/exposure and explore carefully and deeply certain social phenomena without intervention and hypotheses and measurements by utilizing literature in the form of books, articles/ journals, mass media coverage, laws and regulations, and others. Data collection techniques are In-depth interviews and literature studies in books, articles/journals, mass media coverage, reports, laws and regulations, and others.

\section{Results and Discussion}

\subsection{Early Role of Government}

The government's initial role was one of the benchmarks for the success of handling COVID-19. The initial role of the government can be seen from important events related to the spread of COVID-19. Since COVID-19 was identified in Wuhan in December 2019, patients who have reported positive have continued to increase, and the death rate has also continued to increase. The chronology of the spread in Indonesia to the actions taken by the Pekanbaru City Government can be seen in Figure 1.

\begin{tabular}{|c|c|c|}
\hline $\begin{array}{l}\text { March 1, } 2020 \\
\text { First (+) patient in } \\
\text { Indonesia (Depok) } \\
\text { contacts from Japanese } \\
\text { citizens }\end{array}$ & $\begin{array}{l}\text { March 16, } 2020 \\
\text { The Mayor of Pekanbaru } \\
\text { issued a Covid-19 alert } \\
\text { and prevention circular }\end{array}$ & $\begin{array}{l}\text { April 1, } 2020 \\
\text { The Mayor of Pekanbaru } \\
\text { formed a task force to } \\
\text { accelerate the handling of } \\
\text { Covid-19 }\end{array}$ \\
\hline $\begin{array}{l}\text { March } 10,2020 \\
\text { The first death of a } \\
\text { corona patient in } \\
\text { Indonesia was a }\end{array}$ & $\begin{array}{l}\text { March } 16,2020 \\
\text { The Pekanbaru city } \\
\text { government has formed an } \\
\text { integrated team for Covid- } \\
19 \text { response preparedness }\end{array}$ & $\begin{array}{l}\text { April 10, } 2020 \\
\text { DKI Jakarta implements } \\
\text { the first Large-Scale Social } \\
\text { Restrictions in Indonesia }\end{array}$ \\
\hline $\begin{array}{l}\text { March } 13,2019 \\
\text { First }(+) \text { patient in } \\
\text { Pekanbaru with travel } \\
\text { history from Malaysia }\end{array}$ & $\begin{array}{l}\text { March 15, } 2020 \\
\text { Pekanbaru city } \\
\text { government stopped } \\
\text { Car Free Day activities }\end{array}$ & $\begin{array}{l}\text { April 17, } 2020 \\
\text { Pekanbaru implements } \\
\text { Large-Scale Social } \\
\text { Restrictions }\end{array}$ \\
\hline
\end{tabular}

Figure 1. Chronology of the Spread (COVID-19) in Pekanbaru City
Source: 2020 Pekanbaru Mayor Percentage Material at the Corona Virus 19 Handling Webinar in Pekanbaru City “Towards Caring, Inclusive, and Collaborative Governance organized by UIN Suska Riau, Pekanbaru 22 June 2020

Based on Figure 1, it can be seen that there is a link between the events of the spread of COVID-19, which is the basis for policymaking and government actions to the government of Pekanbaru City itself. The escalation of the initial spread in Pekanbaru City, which is getting higher, is a reference for the Pekanbaru City government, which the Riau Provincial government also carries out in determining the emergency response status for COVID-19. 
Table 1. Pre-Large-Scale Social Restriction Activities in Pekanbaru City
This is in line with the presidential instruction and is being followed up by the relevant ministries in the form of guidelines for handling COVID-19 in various sectors. The dominance of activities is still centered on the government but has involved all elements in the government before involving more stakeholders. Some of the activities carried out in the stages before the implementation of Large-Scale Social Restrictions in Pekanbaru City can be seen in Table 1.

\begin{tabular}{|c|c|c|}
\hline NO & TIMES & POLICIES \\
\hline 1 & March 15, 2020 & Temporarily stop Car Free Day (CFD) activities \\
\hline 2 & March 16, 2020 & Increased Alertness and Prevention of COVID-19 \\
\hline 3 & March 16, 2020 & Formation of an Integrated COVID-19 Response Team \\
\hline 4 & March 19, 2020 & $\begin{array}{l}\text { An appeal for Pekanbaru City State Civil Apparatus to Work From Home } \\
(\text { WFH) }\end{array}$ \\
\hline 5 & March 21, 2020 & $\begin{array}{l}\text { City Government Meetings and Regional Leadership Coordination Forum } \\
\text { (FORKOPIMDA) } \\
\text { (Discussing steps to prevent the spread of COVID-19, issuing five } \\
\text { protocols and determining the emergency response status for COVID-19 in } \\
\text { Pekanbaru City) }\end{array}$ \\
\hline 6 & March 23, 2020 & An appeal for Pekanbaru City State Civil Apparatus for Work From Home \\
\hline 7 & March 23, 2020 & $\begin{array}{l}\text { City Government Meetings and the Regional Leadership Coordination Forum } \\
\text { (FORKOPIMDA), religious and community leaders }\end{array}$ \\
\hline 8 & March 23, 2020 & $\begin{array}{l}\text { Instructs the use of online methods in teaching and learning activities for } \\
\text { students to universities }\end{array}$ \\
\hline 9 & March 26, 2020 & $\begin{array}{l}\text { Law enforcement against violations / hindering efforts to prevent the spread } \\
\text { of COVID19 }\end{array}$ \\
\hline 10 & March 30, 2020 & $\begin{array}{l}\text { Extension of the implementation of duties for the State Civil Apparatus of } \\
\text { Pekanbaru City from home }\end{array}$ \\
\hline 11 & April 1, 2020 & Forming a Task Force for the Acceleration of Handling COVID-19 \\
\hline 12 & April 1, 2020 & Restriction of Travel Activities Outside the Region for State Civil Apparatus \\
\hline
\end{tabular}

Source: 2020 Research Processed Data from the Study Document on the Implementation of Large-Scale Social Restrictions to Break the Chain of Distribution of COVID 19 Based on Government Regulation No. 21 of 2020 Pekanbaru City.

Based on Table 1, it can be seen that in less than one month, the Pekanbaru City Government carried out a series of activities and issued several policy products before the implementation of large-scale social restrictions through the Mayor of Pekanbaru Decree No. 325 of 2020. Collaboration initiators are commanded by the government, especially the Mayor, guided by the President's instructions and circular prior to the issuance of provisions related to Large-Scale Social Restrictions in Government Regulation Number 21 of 2020. Several strategic actions were taken by the Pekanbaru City Government in the form of an appeal to study, work and worship at home for a while. It is not only for the community and the City Government's State Civil Apparatus, stopping activities that gather large numbers of people and limiting community mobilization both within the city and residents who enter and leave Pekanbaru City. The final stage, which is included in the Pre-Large-Scale Social Restriction activities, is the formation of the Pekanbaru City COVID-19 Task Force Team in 2020 through the Pekanbaru Mayor's Certificate No. 270. This team became the center for coordination and collaboration of many parties from various sectors/fields in the City government, including other institutions such as the Indonesian National Army, the Police, the Ministry of Religion, the High Court, and the Indonesian Ulema Council of Pekanbaru in other structures. 
Table 2. Role of Non-State Actors in Handling COVID 19 in Pekanbaru City

\subsection{The Entry of Non-State Actors}

Various forms of collaboration involving non-state elements, but still the main role is held by the government as a public body or public agent, which in this case fulfills the mandate and is able to allocate resources to meet the goals of the state and solve problems and fulfill public needs. (Demartoto, 2014). Each party is fully assigned the task of maintaining coordination in planning and implementing programs related to the public interest (Bingham et al., 2005).

At first, non-state actors were seen as part of the executive branch, but the development of collaborative concepts and collaborative governance does have not only a role for the government but also the participation of non-state stakeholders. Actors involved in handling COVID-19 are dominated by elements within the Pekanbaru City Government and involve non-government / State actors and the community. In this research, stakeholders, especially non-state actors, are parties who are involved in handling COVID-19 both in the decision-making process and in handling COVID-19 independently. This is a concern given the similarity of goals in the movement or the efforts made by all parties, namely suppressing the potential for spreading the virus and minimizing its more significant impact. Several non-government / state actors who are identified as involved can be seen in Table 2.
NO 1 Indonesian Ulema Council (MUI)
of Pekanbaru City

\section{THE ROLE OF ACTORS}

The Indonesian Ulema Council of Pekanbaru City was involved in the task force team as deputy daily chairman. The Indonesian Ulema Council of Pekanbaru City has followed up on the Fatwa of the Indonesian Ulema Council in the form of appeals and recommendations for both the government and the community regarding the implementation of worship and other religious life.

2 Forum for Religious Harmony Involved in the process of making mayor regulations regarding (FKUB) of Pekanbaru City guidelines for implementing large-scale social restrictions, especially in relation to the implementation of worship and other religious life.

3 Indonesian Doctors Association Join the task force team as a member of the health sector. (IDI Pekanbaru City) Organizations/institutions in the health sector provide several Indonesian Midwives Association recommendations/guidelines related to handling COVID-19 to (IBI) Pekanbaru City the government and are involved in providing education to the Indonesian National Nurses public and other social movements. City

4 Indonesian Young Entrepreneurs Involve in the process of making mayoral regulations on Association (HIPMI) of guidelines for implementing Large-Scale Social Restrictions Pekanbaru City and providing recommendations regarding handling COVID-19, and assessing the impact of the economy and public areas.Islamic Da'wah Council (MDI) of Pekanbaru City

5 Islamic Da'wah Council (MDI) of Involve in the process of making mayor regulations regarding Pekanbaru City guidelines for implementing large-scale social restrictions, especially related to da'wah activities, organizing worship and other religious life.

6 Riau University Riau Islamic University Riau Caltex Polytechnic (PCR)
Join the task force team as a member of the education sector; besides that, he is also in charge of data collection (analysis and study), policy briefs, and other planning. PCR, in particular, collaborates with the Pekanbaru City Government in the publication of information and data related to the handling of COVID-19 in Pekanbaru City, such as data and distribution maps, infographics, referral hospital info, treatment flow, etc. via the link https://ppc-19. pekanbaru. go id / as well as the development of an android-based application "CIK Puan," which features: Check for COVID-19, Early Warning Destination, Education for COVID-19, Information on Integrated Service Post and Alert Services, etc. 


\begin{tabular}{|c|c|c|}
\hline NO & ACTORS & THE ROLE OF ACTORS \\
\hline 7 & PT. Angkasa Pura II & $\begin{array}{l}\text { Involved in the task force team as a member of the public } \\
\text { transportation and border control sector, especially air } \\
\text { transportation. }\end{array}$ \\
\hline 8 & Pekanbaru Port Authority & $\begin{array}{l}\text { Involve the task force team as a member of the public } \\
\text { transportation and border control sector, especially air } \\
\text { transportation. }\end{array}$ \\
\hline 9 & $\begin{array}{l}\text { PT Sarana Pangan Madani (PT } \\
\text { SPM) through a trading business } \\
\text { unit, namely Rumah Pangan } \\
\text { Madani }\end{array}$ & $\begin{array}{l}\text { Rumah Pangan Madani is a trading business unit of P.T. Sarana } \\
\text { Pangan Madani (PT SPM) which operates as a food distributor } \\
\text { that carries out tasks in services, especially the provision and } \\
\text { distribution of food/aid. }\end{array}$ \\
\hline 10 & $\begin{array}{l}\text { Private Hospital in Pekanbaru } \\
\text { City Region }\end{array}$ & $\begin{array}{l}\text { Several private hospitals in Pekanbaru City have become } \\
\text { referral hospitals for COVID-19 patients }\end{array}$ \\
\hline 11 & $\begin{array}{l}\text { Hamlet Alert COVID-19 } \\
\text { Integrated Environmental } \\
\text { Security System for COVID } 19 \\
\text { Response } \\
\text { Integrated Service Post for } \\
\text { COVID-19 Response } \\
\text { Young Volunteers for Non-Natural } \\
\text { Disaster Response COVID } 19 \\
\text { Citizen Food Granary } \\
\text { The Plenary Mosque }\end{array}$ & $\begin{array}{l}\text { The Pekanbaru City Government formed and set a Hamlet } \\
\text { Alert of COVID-19 in the Pekanbaru City area with a structure } \\
\text { originating from elements of the sub-district, sub-district, } \\
\text { Neighborhood / Hamlet, youth, integrated service centers, } \\
\text { representatives of mosque/house of worship administrators, } \\
\text { Hamlet security (integrated service system, cooperatives/ } \\
\text { community representatives (community food barns) who are } \\
\text { tasked with empowering the community to collect data on the } \\
\text { poor and affected by COVID 19. }\end{array}$ \\
\hline
\end{tabular}

Source: Processed data referring to the Pekanbaru Mayor's Certificate No. 270 Concerning the Formation of the Pekanbaru City Corona Virus Disease 2019 (COVID 19) Task Force Team in 2020 and the Study Document for the Implementation of Large-Scale Social Restrictions in Efforts to Break the Chain of Covid 19 Distribution Based on Government Regulation No. 21 of 2020 in Pekanbaru City.

The involvement of non-state actors is part of maximizing each actor's potential for the same purpose both in the public and private sectors. Collaborative governance of governance emphasizes a combined approach as it applies to laws and regulations relating to public sector provisions. Each actor, both government and private, works collectively in different ways and maximizes different potentials. Relationships and forms of involvement Non-state actors are involved in the structure of the task force team, which is divided based on their respective fields and expertise to coordinate and mobilize resources in carrying out activities to accelerate the handling of COVID-19, including the potential in the community.

\subsection{Joint Decision-Making}

Joint decision-making is when public problems are resolved by a joint decisionmaking process with all parties involved. At its core, collaborative governance is about engaging non-traditional policy actors in decision-making. The internal capacity of the government is not optimal in the implementation of a program or policy so that it is necessary to build networks with other actors (Febrian, 2016). Collaborative governance frameworks integrate the knowledge of individual incentives and multiple collaborative social learning processes of collective action and conflict resolution and institutional arrangements for cross-border collaboration (Emerson et al., 2012). In the emergency response condition, handling COVID-19 in Pekanbaru City, the most important element is making joint decisions. Domination is something that this rapid decision-making process cannot avoid. The Pekanbaru City government's strategy in following up on policies at the central level is strategic enough to quickly form a task force team that consists of many parties with specific roles according to their fields and expertise. Then proceed with joint decision-making related to the implementation of Large-Scale Social Restrictions, Stage 1 to the extension of Stage 3. The activities for the preparation and implementation of Large-Scale Social Restrictions can be seen in Table 3. 
Table 3. Preparation and Implementation of Large-Scale Social Restrictions in Pekanbaru City.

\section{NO DATE OF IMPLEMENTATION \\ ACTIVITIES}

1 April 5, 2020

Formation of a Rapid Assessment Team for the Application of Large-Scale Social Restrictions for Pekanbaru City

2 April 6, 2020

Instructions to the Head of the Sub-District and the Head of the Village to Establish an Integrated COVID-19 Response System

3 April 11, 2020

Coordination Meeting with the Regional Leadership Coordination Forum (FORKOMPIMDA) Riau Province on the Proposal for Large-Scale Social Restrictions in Pekanbaru City to the Minister of Health

\begin{tabular}{cll}
\hline 4 & April 12, 2020 & $\begin{array}{l}\text { Issuance of the Minister of Health's Certificate for Large- } \\
\text { Scale Social Restrictions in Pekanbaru City }\end{array}$ \\
\hline 5 & April 17, up to April 30, 2020 & $\begin{array}{l}\text { The Enforcement of Large-Scale Social Restrictions for } \\
\text { Pekanbaru City (Pekanbaru Mayor Decree No. 325 of 2020) }\end{array}$ \\
\hline 6 & May 1, up to May 14, 2020 & $\begin{array}{l}\text { Extension of Large-Scale Social Restrictions Stage II } \\
\text { (Pekanbaru Mayor's Decree No.358 of 2020) }\end{array}$ \\
\hline 7 & May 15, up to May 28, 2020 & $\begin{array}{l}\text { Extension of Large-Scale Social Restrictions Stage III } \\
\text { (Pekanbaru Mayor's Decree No.375 of 2020) }\end{array}$ \\
\hline
\end{tabular}

Source: Processed Research Data from Reports on the Implementation of Large-Scale Social Restrictions in stages I, II, and III of Pekanbaru City

Based on Table 3, it can be seen that several activities emphasize collaboration aspects both in the form of tiered coordination and communication, starting from reviewing applications to obtaining permits to implement large-scale social restrictions and their extension by the Minister of Health. In stage I of Large-Scale Social Restrictions, the case development was relatively high in this early stage since the discovery of the first case. where in just 35 days, the increase in cases reached 100 points. Within five weeks, the spread of cases had covered all sub-districts in Pekanbaru City, but there were no local transmission incidents yet. Collaboration is carried out both from the health sector, the social sector, the peace and order sector, and the social safety net sector. Still, with the high number of cases, both People Under Monitoring (ODP), Patients Under Supervision (PDP), and positive cases and low levels of discipline and community compliance, the Pekanbaru City Government decided to extend the implementation of large-scale social restrictions.

In the Large-Scale Social Restrictions stage II to III of the case development, there is a trend of decreasing the number of Insider People Under Monitoring, Patients Under Supervision, and positive cases. A series of activities that emphasize the aspect of collaboration is seen in restrictions on schools' learning activities, restrictions on business premises and public places, restrictions on the movement of people and goods, restrictions on places of worship, and social safety nets. The main obstacle is still related to the low level of discipline and community compliance. The extension of the time for the implementation of large-scale social restrictions in Pekanbaru City was again carried out. In the implementation of Large-Scale Social Restrictions up to stage III in Pekanbaru City, there is effectiveness in suppressing the increase in COVID-19 cases. However, there are still problems where there are high violations of Large-Scale Social Restrictions by the community. This occurs due to low awareness and weak enforcement of sanctions from the start of Large-Scale Social Restrictions. The sanctions were given at the beginning of the implementation of Large-Scale Social Restrictions. It is regulated in the Pekanbaru Mayor's Regulation regarding Large-Scale Social Restrictions, are only administrative fines and written warnings for business entities. Then additional social sanctions are carried out at the final stage of the 
Table 4. Number of

Reprimands Issued During the Implementation of Large-Scale Social Restrictions I, II, III in Pekanbaru City
Table 5. Covid-19 Handling Team in Pekanbaru City implementation of Large-Scale Social Restrictions. The witness was deemed unable to provide a deterrent effect on the community at the start of implementing large-scale social restrictions. The sanctions in the form of a warning during the implementation of large-scale social restrictions in Pekanbaru City can be seen in Table 4.

\begin{tabular}{ccccc}
$\begin{array}{c}\text { LARGE-SCALE } \\
\text { SOCIAL } \\
\text { RESTRICTIONS }\end{array}$ & $\begin{array}{c}\text { REPRIMAND } \\
\text { AGAINST } \\
\text { CLOSING } \\
\text { BUSINESS } \\
\text { PLACES }\end{array}$ & $\begin{array}{c}\text { REPRIMAND } \\
\text { AGAINST } \\
\text { VEHICLES NOT } \\
\text { COMPLIANT } \\
\text { WITH LARGE- } \\
\text { SCALE SOCIAL } \\
\text { RESTRICTIONS }\end{array}$ & $\begin{array}{c}\text { REPRIMAND } \\
\text { AGAINST } \\
\text { PEOPLE NOT } \\
\text { WEARING } \\
\text { MASKS }\end{array}$ & $\begin{array}{c}\text { WARNING } \\
\text { AGAINST } \\
\text { PEOPLE TO STAY } \\
\text { AT HOME }\end{array}$ \\
\hline Stage I & 1.199 & 4.261 & 5.077 & 3.520 \\
\hline Stage II & 650 & 2.310 & 2.738 & 1.899 \\
\hline $\begin{array}{c}\text { Stage III } \\
\text { (up to day 12) }\end{array}$ & 301 & 1.176 & 1.691 & 1.176 \\
\hline Source: Pekanbaru City Large-Scale Social Restriction Evaluation Report Phase III from May, 2020 & \\
\hline
\end{tabular}

In collaborative government, the problem of power imbalance may occur, where the decision-making process may be dominated by the strongest actors who are related to the interests concerned (Mukhlis et al., 2018). In the early stages of policymaking to the implementation of Large-Scale Social Restrictions, which is actualization in decision making, is dominated by the government as the strongest actor, the involvement of non-state actors is more to the portions of activities that utilize the potential and interests of each actor. Decision-making in an emergency response condition is also one of the important reasons for the government's use of dominant power. Still, it is considered quite effective in reducing the number of cases but has not effectively changed people's lives.

\subsection{Formal Organizing}

Formal organizing can be seen from the structures formed that involve non-state actors and in which stakeholders hold a balance of power. Formal organizing is also related to strategies for capacity building so that it can provide an overview of developing human resource potential and contributing to the development of the collective capacity of the organization (Amin et al., 2016).

In handling COVID 19 in Pekanbaru City, a formal organization can be seen from the team formed, which becomes the center of coordination and collaboration of many parties under the leadership of the Mayor of Pekanbaru. The teams formed by the Pekanbaru City Government can be seen in Table 5.

\begin{tabular}{|c|c|c|c|}
\hline NO & NAME OF TEAM & JOB DESCRIPTION & MEMBERSHIP \\
\hline 1 & $\begin{array}{l}\text { Integrated Team on } \\
\text { COVID-19 Infection } \\
\text { Response Readiness }\end{array}$ & $\begin{array}{l}\text { Service at an early stage prior } \\
\text { to the imposition of Large-Scale } \\
\text { Social Restrictions. The team's } \\
\text { task is related to preparedness, } \\
\text { such as monitoring the } \\
\text { number and spread of } \\
\text { cases, local transmission } \\
\text { incidents, local readiness, } \\
\text { and operationalization of } \\
\text { social safety nets and security } \\
\text { aspects. }\end{array}$ & $\begin{array}{l}\text { The team formed based on the } \\
\text { Mayor's Decree is chaired by } \\
\text { the Pekanbaru Village Secretary } \\
\text { with membership from the } \\
\text { Pekanbaru City government. }\end{array}$ \\
\hline
\end{tabular}




\begin{tabular}{|c|c|c|c|}
\hline NO & NAME OF TEAM & JOB DESCRIPTION & MEMBERSHIP \\
\hline 2 & $\begin{array}{l}\text { Task Force for the } \\
\text { Acceleration of Handling } \\
\text { covID-19 }\end{array}$ & $\begin{array}{l}\text { The task force is the leading } \\
\text { sector in implementing } \\
\text { operations and control of } \\
\text { handling COVID-19, as } \\
\text { well as coordinating and } \\
\text { supervising the implementation } \\
\text { of accelerated handling of } \\
\text { coVID-19. }\end{array}$ & $\begin{array}{l}\text { The team, which is chaired } \\
\text { directly by the Mayor of } \\
\text { Pekanbaru, is a combination } \\
\text { of many elements of the } \\
\text { Pekanbaru City government } \\
\text { and other stakeholders from } \\
\text { the Indonesian National Army, } \\
\text { the Police, the Ministry of } \\
\text { Religion, the High Court, the } \\
\text { Indonesian Ulama Council, } \\
\text { the Riau Malay Customary } \\
\text { Institution, the Indonesian } \\
\text { Journalists Association, } \\
\text { and Private Hospitals. , A } \\
\text { professional organization in the } \\
\text { health sector, P.T. Madani Food } \\
\text { Facilities and COVID-19 Alert } \\
\text { Hamlet with a total membership } \\
\text { of more than } 100 \text { positions. }\end{array}$ \\
\hline 3 & $\begin{array}{l}\text { Research Team for } \\
\text { Large-Scale Social } \\
\text { Restrictions Policy Plans } \\
\text { in Pekanbaru City }\end{array}$ & $\begin{array}{l}\text { It is conducting a } \\
\text { comprehensive study of the } \\
\text { impact of COVID-19 as a basis } \\
\text { for decision making regarding } \\
\text { the extension and a report } \\
\text { on the implementation of the } \\
\text { Large-Scale Social Restrictions. }\end{array}$ & $\begin{array}{l}\text { The team, which is chaired } \\
\text { directly by the Mayor of } \\
\text { Pekanbaru, is a combination } \\
\text { of many elements of the } \\
\text { Pekanbaru City government and } \\
\text { other stakeholders }\end{array}$ \\
\hline 4 & $\begin{array}{l}\text { The Integrated Team for } \\
\text { Enforcement of Large- } \\
\text { Scale Social Restrictions }\end{array}$ & $\begin{array}{l}\text { In charge of supervising, } \\
\text { controlling, escorting, and } \\
\text { enforcing the law for offenders } \\
\text { during the implementation } \\
\text { of the Large-Scale Social } \\
\text { Restrictions }\end{array}$ & $\begin{array}{l}\text { Chaired by the Pekanbaru City } \\
\text { Police Chief and membership } \\
\text { consists of elements from the } \\
\text { Pekanbaru Military District } \\
\text { Commander 0301, the City } \\
\text { Police, the Riau Regional } \\
\text { Police, the Civil Service Police } \\
\text { Unit, and the Department of } \\
\text { Transportation Service. }\end{array}$ \\
\hline
\end{tabular}

Source: Processed Research Data, 2020

Based on Table 5 , it can be seen that the formation of a formal structure is based on the need for handling COVID-19 and accommodating potential stakeholders in various sectors. However, if you look closely, the formed team was not only the organizational structure that was too large in number and was still dominated by elements of the regional government. The imbalance of power/ability and task load cannot be avoided so that not all team elements can collaborate well. Problems related to the absence of regional regulations, human resources, budget, and infrastructure are still the main obstacles in optimizing this formal organization.

\subsection{Getting Consensus}

The term collaborative denotes a deliberative and consensus-oriented approach. Obtaining consensus on handling COVID-19 certainly cannot be separated from joint decision making, both pre-Large-Scale Social Restrictions, Phase I, II, and Large-Scale Social Restrictions. Consensus taking can be seen from several sectors, including health, the social sector, the security and order sector, the information communication sector, and the social safety net sector, which can be seen in Table 6.

Table 6. Handling of COVID-19 by Sector in Pekanbaru City

\begin{tabular}{llll} 
NO & SECTOR & \multicolumn{1}{c}{ ELEMENT } & DESCRIPTION \\
\hline 1 & Health & $\begin{array}{l}\text { It consists of Pekanbaru City } \\
\text { Government together with } \\
\text { professional organizations and } \\
\text { government / private hospitals }\end{array}$ & $\begin{array}{l}\text { Collaborate in carrying out health } \\
\text { management and assessment of the } \\
\text { development and distribution of cases }\end{array}$ \\
\hline
\end{tabular}




\begin{tabular}{|c|c|c|c|}
\hline NO & SECTOR & ELEMENT & DESCRIPTION \\
\hline 2 & Social & $\begin{array}{l}\text { It consists of the Pekanbaru City } \\
\text { Government and the Ministry of } \\
\text { Religion, the Indonesian Ulema } \\
\text { Council, the Forum for Religious } \\
\text { Harmony, universities, and the } \\
\text { community. }\end{array}$ & $\begin{array}{l}\text { Collaborate in regulating and supervising } \\
\text { social activities and physical distancing } \\
\text { in places of worship, entertainment } \\
\text { venues, markets, and shopping centers } \\
\text { to private / government offices. }\end{array}$ \\
\hline 3 & $\begin{array}{l}\text { Security and } \\
\text { Order }\end{array}$ & $\begin{array}{l}\text { It consists of the Pekanbaru City } \\
\text { Government in collaboration } \\
\text { with the Indonesian National } \\
\text { Police, the Indonesian National } \\
\text { Army }\end{array}$ & $\begin{array}{l}\text { Collaborate in security and order at } \\
\text { five checkpoint locations (Monitoring } \\
\text { Locations) with targets, namely business } \\
\text { premises, drivers, and vehicle capacity, } \\
\text { and provide action against violations } \\
\text { in the form of a verbal warning, written } \\
\text { warning, and law enforcement to court. }\end{array}$ \\
\hline 4 & $\begin{array}{l}\text { Information } \\
\text { and } \\
\text { Communication }\end{array}$ & $\begin{array}{l}\text { It consists of the Pekanbaru } \\
\text { City Government, universities, } \\
\text { mass media to the community }\end{array}$ & $\begin{array}{l}\text { Collaborate in data collection and } \\
\text { management, development of } \\
\text { information and communication systems, } \\
\text { development of public communication } \\
\text { strategies, and media monitoring. }\end{array}$ \\
\hline 5 & $\begin{array}{l}\text { Social Safety } \\
\text { Net }\end{array}$ & Pekanbaru City Government & $\begin{array}{l}\text { Recipients of assistance are included } \\
\text { in Social Welfare Data (DTKS) which } \\
\text { consists of recipients of assistance from } \\
\text { The Hope Family Program (PKH), Non- } \\
\text { Cash Food Assistance (BPNT), and Direct } \\
\text { Cash Assistance (BLT) COVID 19, as well } \\
\text { as assistance for communities affected } \\
\text { by COVID } 19 \text { in the form of assistance } \\
\text { from Bulog's Government Rice Reserve } \\
\text { (CBP) and rice and side dishes from } \\
\text { Pekanbaru City's Local Government } \\
\text { Budget. }\end{array}$ \\
\hline
\end{tabular}

Source: Processed Research Data, 2020

\subsection{Collaborative Problems Regarding Public Policy and Services}

Collaborative governance also identifies implementation problems related to policies and the handling of COVID-19. According to (Ansell \& Gash 2008) stated that general issues of collaboration are more due to unbalanced resources and authority, differences in actor power, conflict, cooperation between actors, and incentives to collaborate. Several issues that affect collaborative governance regarding policy are related to the complexity of policy change. Disaster situations that require integration between the central government and regional governments and require a fast and adaptive response are not easy to do. Indeed, a series of policy "trials" is carried out, which results in slow handling. Consistency and commitment are the main benchmarks in policy implementation, but it is difficult to do if policies change over time and affect collaborative work. Besides, the problem of the organizational structure's capacity, both internal to the government and other non-state actors, has resulted in conditions that are not optimal in handling COVID-19 in several fields in carrying out their duties for this common goal. Communication and coordination is also a problem because it has not become a priority for programs/activities that are carried out sustainably by emphasizing partnerships with other stakeholders (Bachrein, 2012).

Collaborative issue in public services, especially the handling of COVID-19 in Pekanbaru City, can be identified, including the inadequate role of the team formed, lack of socialization, and publication before and after large-scale social restrictions. Besides, law enforcement that is not evenly distributed and has not provided a deterrent effect, distribution of aid that has not been implemented has even resulted in conflict, the role of institutions and actors in the socio-religious sector is minimal, to differences in perceptions of the application of large-scale social restrictions and law 
enforcement between regions and other districts. The collaboration issue in public services was also exacerbated by the low awareness of the people of Pekanbaru City regarding the existence and spread of COVID-19. The high level of violations during the implementation of Large-Scale Social Restrictions both in houses of worship, markets, private / government offices, and other public areas.

\section{Conclusion}

Handling COVID-19 in Pekanbaru City is an adaptation process that is carried out quickly, both from the policy aspect to the government's actions. Government collaborative governance elaborates on six elements, namely the initial role of government, the inclusion of non-state actors, joint decision making, formal organizing, obtaining consensus, and there are problems to collaborate both on public policies and services. It can be concluded that the collaborative governance built-in handling COVID-19 is still not optimal. This is indicated by an imbalance of power as seen from the Regional Government's dominance in decision-making and the not yet optimal involvement of all other non-state actors. Even though the implementation of stage III of the Large-Scale Social Restrictions is considered to have been effective in efforts to suppress the increase in COVID-19 cases, there are problems in collaboration related to both the complexity of policy changes, the capacity of organizational structures, communication and coordination issues, law enforcement that has not been optimal in terms of both aspects. Policies and low public awareness so that there are still highscale violations of the implementation of Large-Scale Social Restrictions. It is hoped that the handling of COVID-19 in Pekanbaru City will suppress and break the chain of distribution with the primary key, namely optimizing the active role of all stakeholders and the community itself and creating a progressive strategy that is always oriented towards strengthening collaborative itself.

\section{References}

Allain-Dupré, D., Chatry, I., Michalun, V., \& Moisio, A. (2020). The territorial impact of COVID-19: managing the crisis across levels of government. OECD Tackling Coronavirus, April, 2-44. https://www.oecd.org/ coronavirus/policy-responses/theterritorial-impact-of-covid-19-managing-the-crisis-across-levelsofgovernment-d3e314e1/

Amin, R. M.,' I., \& Febrina, R. (2016). Strategi Pemberdayaan Masyarakat Melalui Pengembangan Kapasitas Kelembagaan Kampung Adat Di Kabupaten Siak Provinsi Riau. Jurnal Ilmu Pemerintahan Nakhoda, 15(26), 65-77. https://doi.org/10.35967/jipn.v15i26.3844

Ansell, C., \& Gash, A. (2008). Collaborative governance in theory and practice. Journal of Public Administration Research and Theory, 18(4), 543-571. https://doi.org/10.1093/jopart/mum032

Arrozaaq, D. L. C. (2016). Collaborattive Governance (Studi Tentang Kolaborasi Antar Stakeholders Dalam Pengembangan Kawasan Minapolitan di Kabupaten Sidoarjo). Kebijakan Dan Manajemen Publik, 3, 1-13. http://repository.unair.ac.id/67685/

Astari, M. M., Mahsyar, A., \& Parawangi, A. (2019). Kolaborasi Antarorganisasi Pemerintah Dalam Penertiban Moda Transportasi Di Kota Makassar (Studi Kasus Kendaraan Becak Motor). JPPM: Journal of Public Policy and Management, 1(1), 1-8. https://journal.unismuh.ac.id/index.php/jppm/article/view/2575

Bachrein, S. (2012). Pengembangan Daerah Aliran Sungai (DAS) Cikapundung: Diagnostik Wilayah. Jurnal Bina Praja, 04(04), 227-236. https://doi.org/10.21787/jbp.04.2012.227-236

Balakrishnan, V. S. (2020). COVID-19 response in central Asia. The Lancet Microbe, 1(7), e281. https://doi. org/10.1016/s2666-5247(20)30177-4

Bingham, L. B., Nabatchi, T., \& O'Leary, R. (2005). The New Governance: Practices and Processes for Stakeholder and Citizen Participation in the Work of Government. Public Administration Review, 65(5), 547-558. http://www.jstor.org/stable/3542521

Chatterjee, R., Bajwa, S., Dwivedi, D., Kanji, R., Ahammed, M., \& Shaw, R. (2020). CoVID-19 Risk Assessment Tool: Dual application of risk communication and risk governance. Progress in Disaster Science, 7, 100109. https://doi.org/10.1016/j.pdisas.2020.100109

Demartoto, A. (2014). Efektivitas Collaborative Governance dalam Pelayanan Komprehensif Berkesinambungan untuk Menanggulangi HIV / AIDS Effectivity of Collaborative Governance in Sustainable Comprehensive Service to Cope with HIV / AIDS. 3-4. https://journal.fkm.ui.ac.id/kesmas/ article/view/753

Djalante, R., Lassa, J., Setiamarga, D., Sudjatma, A., Indrawan, M., Haryanto, B., Mahfud, C., Sinapoy, M. S., Djalante, S., Rafliana, I., Gunawan, L. A., Surtiari, G. A. K., \& Warsilah, H. (2020). Review and analysis of current responses to COVID-19 in Indonesia: Period of January to March 2020. Progress in Disaster Science, 6, 100091. https://doi.org/10.1016/j.pdisas.2020.100091 
Económico, O. para a C. e D. (2020). Innovation, development and CoviD-19: Challenges, opportunities and ways forward. 1-14. https://read.oecd-ilibrary.org/view/?ref=1059_1059289s3 nykmbav2\&title=Innovation-development-and-COVID-19-Challenges-opportunities-and-waysforward\&_ga=2.171705184.1961674759.1621423313-1963885453.1621244215

Égert, B., Guillemette, Y., Murtin, F., \& Turner, D. (2020). Walking the tightrope: avoiding a lockdown while containing the virus. OECD Economics Department Working Papers, No. 1633, 1-28. https:// oecdecoscope.blog/2020/12/08/walking-the-tightrope-avoiding-a-lockdown-while-containing-thevirus/

Emerson, K., Nabatchi, T., \& Balogh, S. (2012). An Integrative Framework for Collaborative Governance. Journal of Public Administration Research and Theory: J-PART, 22(1), 1-29. https://www.jstor.org/ stable/41342607

Febrian, R. A. (2016). Collaborative Governance In The Development Of Rural Areas (Review of the Draft and Regulation). Wedana, II, 200-208. https://journal.uir.ac.id/index.php/wedana/article/view/1824

Furqoni, I., \& Rosyadi, S. (2019). Collaborative Governance in Corporate Social Responsibility Forum in Banyumas Regency. Jurnal Bina Praja, 11(2), 209-217. https://doi.org/10.21787/jbp.11.2019.209217

Kisielewska, M., \& Richter, A. (2020). COVID-19 Crisis Response in South East European Economies. Oecd, May, 23. https://read.oecd-ilibrary.org/view/?ref=129_129649-tclugxbw4j\&title=COVID-19-CrisisResponse-in-South-East-European-Economies\%0A

Moleong, L. J. (2007). Metodologi Penelitian Kualitatif. PT Remaja Rosdakarya Offset.

Mukhlis, M., Nazsir, N., Rahmatunnisa, M., \& Yani Yuningsih, N. (2018). The Actor Domination in the Collaborative Governance in the Lampung Province Central Government Displacement Policy: An Ambivalent. Jurnal Ilmiah Peuradeun, 6(3), 507. https://doi.org/10.26811/peuradeun.v6i3.272

OECD. (2020a). Covid-19 in Latin America and the Caribbean: An overview of government responses to the crisis. Tackling Coronavirus (Covid 19): Contributing to a Global Effort, November, 1-31. https://www. oecd.org/coronavirus/policy-responses/covid-19-in-latin-america-and-the-caribbean-an-overview-ofgovernment-responses-to-the-crisis-0a2dee41/

OECD. (2020b). COVID-19 in Latin America and the Caribbean: Regional socio-economic implications and policy priorities. Oecd, 1-12. https://www.oecd.org/coronavirus/policy-responses/covid-19-in-latinamerica-and-the-caribbean-regional-socio-economic-implications-and-policy-priorities-93a64fde/

Priyo Purnomo, E., Ramdani, R., Setyadiharja, R., \& Muzwardi, A. (2018). Collaborative Governance Tata Kelola Hutan Berbasis Masyarakat (2018th ed., Issue 1). Lembaga Penelitian, Publikasi dan Pengabdian Masyarakat (LP3M) Universitas Muhammadiyah Yogyakarta. http://repository. umy.ac.id/bitstream/handle/123456789/20030/CollaborativeGovernance_revisi.compressed. pdf?sequence=1\&isAllowed =y

Sepriandi, S., \& Hussein, R. (2019). Faktor-Faktor yang Mempengaruhi Collaborative Governance dalam Penanganan Pekerja Migran Bermasalah di Kota Tanjungpinang. JPPUMA Jurnal Ilmu Pemerintahan Dan Sosial Politik Universitas Medan Area, 7(1), 81. https://doi.org/10.31289/jppuma.v7i1.2175

Shaw, R., Kim, Y., \& Hua, J. (2020). Governance, technology and citizen behavior in pandemic: Lessons from COVID-19 in East Asia. Progress in Disaster Science, 6, 100090. https://doi.org/10.1016/j. pdisas.2020.100090

Subhan, A. (2016). Multidirectional Networks of Government Transparency: A Preliminary Model. Jurnal Bina Praja, 8(2), 209-219. https://doi.org/10.21787/jbp.08.2016.209-219

Sukmana, M., Aminuddin, M., \& Nopriyanto, D. (2020). Indonesian government response in CoVID-19 disaster prevention. East Afrian Scholars Journal of Medical Sciences, 3(3), 81-86. https://doi. org/10.36349/EASMS.2020.v03i03.025 